\title{
The Mirror of Language
}

A Study in the Medieval Theory of Knowledge

by Marcia L. Colish

Carefully tracing the development of the design theory in Augustine, Anselm, Aquinas, and Dante, this interpretation of medieval symbolism roots it in a verbal theory of signs derived from Biblical and classical sources. 90s net

\section{The Presence of the Word}

Some Prolegomena for Cultural and Religious History

by Walter J. Ong

'Now that the other eminent Catholic-electronic prophet, Marshall McLuhan, seems to have gone into orbit with his fantasy-probes, we shall no doubt need to attend more closely to Fr. Ong, who says so many of the same things but appears to say them more judiciously.'

\section{Yale University Press \\ 70 Great Russell Street, London WC1}

M. R. AYERS

The Refutation of Determinism

AN ESSAY IN PHILOSOPHICAL LOGIC

An original contribution to philosophical studies which effectively shows the error in all the most plausible contentions of the Determinist, and has far-reaching implications for philosophical psychology. $37 \mathrm{~s} 6 \mathrm{~d}$ 


\section{A Critique of British Empiricism}

\section{Fraser Cowley}

From the viewpoint of a phenomenologist, Fraser Cowley has written an interesting and persuasive critique of such empiricist philosophers as Hume, Russell and Ayer.

42s

\section{Pleasure and Pain}

\section{J. L. Cowan}

Professor Cowan's basic thesis is that the best non-dualistic thought in modern philosophy and psychology has failed to recognise the solidity of the grounds on which mind-body dualism rests, just as dualists have failed to appreciate the devastating character of the arguments that can be marshalled against them.

$36 \mathrm{~s}$

\section{Kant's Theory of Knowledge}

\section{Justus Hartnack}

A clear and concise guide to the problems of Kant's Critique of Pure Reason.

$36 \mathrm{~s}$

\section{Space and Time}

\section{Richard Swinburne}

This major work is concerned with the properties which Space and Time must have as a matter of logical necessity and with the most general contingent spatio-temporal properties of our Universe.

63s, August

\section{macmilan}




\section{The Individual in}

\section{Society}

\section{A. L. MACFIE}

Seeks to illustrate the massive series of studies by Adam Smith through which he hoped to complete his system of moral, social and natural philosophy.

'Professor Macfie has written an impressively important book.' New Society.

$36 \mathrm{~s}$.

\section{Portrait of a Man Standing}

\section{SALVADOR DE MADARIAGA}

The author sketches 'a portrait of life for our times'. He regards all man's activities as determined by two tendencies which enter into every form of life.

'Every page is stimulating.' Times Literary Supplement.

'One of the richest intellects today.' Irish Times.

\section{The Logic of Choice}

\section{G. A. D. GOTTLIEB}

A critical study of the concept of rule used in law, ethics and much philosophical analysis which the author uses to investigate the concept of rationality.

$30 \mathrm{~s}$.

\section{Kierkegaard's Authorship}

\section{G. B. ARBAUGH and G. E. ARBAUGH}

The only comprehensive treatment of the popular writings of the eccentric Danish philosopher, poet and theologian who originated existential modes of thought.

$63 \mathrm{~s}$.

\section{Man in Search of Himself}

\section{JEAN CHARON}

A physicist demonstrates the futility of total specialisation in this technological world and shows how the intellectual caveman can break free of his den.

'Dr Charon has made an impressive attempt to integrate the major activities of human existence.' SIR BERNARD LOVELL.

\section{BURTON F. PORTER}

In examining the logical arguments associated with the Naturalistic Fallacy, the author is led to discuss mysticism, the Mediaeval attitude towards faith and reason and the linguistic approach to philosophical theology.

\section{General Metaphysics}

\section{GOTTFRIED MARTIN}

The author offers a systematic analysis of various interpretations of individual and general being. He presents the writings of Plato, Aristotle and Kant as paradigms of three standard metaphysical standpoints and shows how the generality present in the sciences of logic, arithmetic, geometry and physics, is given a characteristically different interpretation in each case.

$60 s$.

\section{The Senses Considered as Perceptual systems}

\section{JAMES J. GIBSON}

The author reconsiders the ancient problem of sense perception in a new way of considering perception and the senses together within the framework of evolution. The book contains many challenging issues which, together with its convincing conclusions, make it a work which will command the attention of academics and their students. $40 \mathrm{~s}$.

\section{Deity and Morality}

\section{GEORGE ALLEN \& UNWIN}




\section{THE IDENTITY THEORY OF MIND}

\section{F. Presley}

What is the relationship between the mental and the physical? Does the Identity Theory-that mental states are as a matter of contingent fact, identical with states of the brain-provide a satisfactory answer?

This is the focal point of this series of papers presented by prominent philosophers from Australian Universities at the Annual Congress of the Australasian Association of Philosophy in 1964. Professor Presley of the University of Queensland provides a unifying introduction to a book which may well be used as a basis for the critical examination of the Identity Theory of Mind.

184 pages, cloth, $\$ 4.25$

\section{UNIVERSITY OF QUEENSLAND PRESS} for books of more than academic interest

Volume X

No. 1

\section{JUNE 1968}

\section{RATIO}

edited by STEPHAN KÖRNER

W. STEGMÜLLER:

Towards a Rational Reconstruction of Kant's Metaphysics of Experience, Part II

Peter Winch:

JÜRGEN MITTELSTRASS:

Wittgenstein's Treatment of the Will

Predication and Recurrence of the Same

WolfGang Yourgrau AND

CHARLES WORKS:

A New, Formalized Version of the Verifiability Prínciple

RICHARD S. WESTFALL:

Huygens's Rings and Newton's Rings: Periodicity and Seventeenth Century Optics

Review:

GRAHAM Bond: Studies in the Philosophy of Kant (Lewis White Beck)

Price 15s.

Annual Subscription 27s. 6d. net

BASIL BLACKWELL • OXFORD 


\section{Papers on Time and Tense}

\section{ARTHUR N. PRIOR}

In eight of these papers the author of Past, Present and Future develops informally his views on the nature of temporal facts, and in five others solutions to technical problems.

30s. net

\section{On Science, Necessity and the Love of God}

\section{Essays by SIMONE WEIL \\ Selected and Translated by RICHARD REES}

In this, the latest of his editions of the work of Simone Weil, Sir Richard Rees has brought together material mainly from her notebooks and essays published posthumously. The first section of the book deals particularly with science and forms an important part of Simone Weil's general criticism of the moral and intellectual sterility of modern culture. The essays in the second part deal with Greek philosophy, literature and religion. 42s, net

\section{John Locke: Epistola de Tolerantia}

A Letter on Toleration

\section{Latin Text edited by}

\section{RAYMOND KLIBANSKY}

\section{English translation by J. W. CLOUGH}

This is a critical edition, with a new and more accurate translation, of Locke's letter written in exile in Holland in 1689 and published there anonymously. The history of the text is traced from manuscript material in Oxford and in Dutch libraries, and in an Introduction, Locke's theory is analysed and discussed. Second edition. 2 plates 40 s. net

\section{OXFORD}

\section{UNIVERSITY PRESS}

THE PHILOSOPHICAL QUARTERLY

Contents of Volume 18, No. 72, July 1968 Articles

I. Particulars and their Qualities

Douglas C. Long

II. Incorrigibility George Nakhnikian

III. Austin on Entailment Richard T. Garner

IV. "And That's A Promise" Pall S. Ardal

V. The Self-Regarding and Other-Regarding Virtues

Gabriele Taylor and Sybil Wolfram Discussions

I. On the Validity of Argument from Fact to Value-Judgement $P$. D. Shaw

II. Plamenatz on Consent and Obligation Frederick Siegler

III. Gewirth and Categorial Consistency

Book Reviews

N. Fotion

List of Books Received

Edited by G. P. Henderson with the assistance of Anthony Ralls and L. C. Holborow, and of Anthony Ralls and $L$. C. Holborow, and the University of St. Andrews.

Price twenty-five shillings per annum (in U.S.A. \$4.00), post free, for orders placed directly with the Treasurer (Miss J. S. M. directly with the Treasurer (Miss J. S. M. or the Assistant Treasurer (Prof. V. C. Chappell, Dept. of Philosophy, University of Chicago, Chicago 60637, Illinois, U.S.A.) For orders placed through booksellers or agents the price is thirty shillings per annum (in U.S.A. $\$ 5.00$ ).

\section{Back Issues of Journals} in

\section{THE HUMANITIES AND SCIENCES}

$$
\text { always required by }
$$

Wm. DAWSON \& SONS Ltd

Back Issues Department,

16 West Street

$$
\text { FARNHAM }
$$

Surrey, England

Telephone: Farnhom 4664

(OAL 13 4664)

Cables: Dawbooks Farnham 
mS

\section{Philosophy, Politics and Society}

\section{Third Series}

\section{Edited by PETER LASLETT}

and W. G. RUNCIMAN

The contributors are A. J. Ayer, Charles Taylor, Jolnn Rawls, C. B. MacPherson, Hannah Arendt, S. M. Lukes, R. M. Hare, John Plamenatz, Bernard Crick, Kenneth J. Arrow.

631048901

3os. net

\section{Religion and Understanding}

\section{Edited by D. Z. PHILLIPS}

The contributors are R. P. Anschutz, R. G. Collingwood, R. F. Holland, J. R. Jones, Norman Malcolm, D. Z. Phillips, W. H. Poteat, Norman Kemp Smith and Peter Winch.

631104100

30s. net

\section{BASIL BLACKWELL}

\section{MIND}

A Quarterly Review of Psychology and Philosophy

Edited by: Prof. GILBERT RYLE

I. The Seventh Letter of Plato: M. LEVISON, A. Q. MORTON, and A. D. WINSPEAR

II. Proper Names: RICHARD CAMPBELL

III. On the Conception of Polylogic: GEORGE BRUTIAN

IV. The Precepts of Justice: J. I. MacADAM

V. Unfulfilled Conditionals and the Truth of their Constituents: JONATHAN HARRISON

VI. Value Judgements and Action: L. W. SUMNER

VII. Discussion Notes:

Hare's Debtors: D. P. GAUTHIER

The Regress Arguments in the Republic: D. R. DUFF-FORBES

Chisholm on Knowledge and Principles: BERNARD ROSEN

Actions, Brain-Processes, and Determinism: R. E. EWIN

On a Finitist "Solution" to some Zenonian Paradoxes: G.A. WEDEKING R. M. Hare and Moral Reasoning: G. H. HARMAN

Zeno and Continuity: LEIGH VAN VALEN

Has Lee Finally caught Zeno? DONALD MOOR

VIII. Critical Notices:

The Commonplace Book of G. E. Moore (1919-1953). Edited by Casimir Lewy Lectures on Philosophy. By G. E. Moore. Edited by Casimir Lewy (G. J. WARNOCK)

Contemporary Moral Philosophy. By G. J. Warnock (R. M. HARE)

IX. New Books

$\mathrm{X}$. Notes

Published for the MIND ASSOCIATION by

BASIl BLACKWELL, 49 Brond Street, Oxford 


\title{
New books from Regency Press
}

\author{
THE FUTURE OF MAN \\ by $H$. W. HEASON
}

Scientists become faced with an ever increasing dilemma the more advanced become their techniques. This is illustrated in ethical problems raised in regard to organ transplants and the development of ever more potent weapons of mass destruction.This book is intended to bring all this work together, and show that a brand new approach to science itself can be initiated.

Cloth Bound 30s. net. Illustrated. (by post 32s. 6d. or U.S.A., Canada etc., \$5.00)

\section{WHAT NEXT? \\ by DAISY O. ROBERTS}

Mrs Roberts believes that she has been the amanuensis of a research group on the other side of death which has been interested in probing problems of human life. The automatic writings consist of the experience of a doctor; a miner; a curio collector; a zoo attendant; a French prison guard; a Member of Parliament and a score of others.

\author{
Cloth Bound 21s. Net (By post 22s. 6d. or U.S.A., Canada etc, \$3.75)
}

\section{MY FATHER'S HOUSE by DEDIAN VANDERSTAAY}

After her 17-year-old daughter had suddenly passed away, the authoress felt so hopelessly miserable that she could hardly go on living and she prayed that, if there should be a personal existence after death, she might learn more of this. The phenomena began to happen that were convincing to her and which proved to be enlightening and comforting, so that she could go on living again.

Cloth Bound 21s. Net (By Post 22s. 6d. or U.S.A., Canada \$3.75)

\section{SUN CHILDREN OF RA \\ by ASTA KINDLER}

Unique and controversial book, written as fiction but based on stark fact, of the savage struggle between' the Sun-children and the Giffnas. Alive with newly revealed occult truths and designations, the reader is transported to the realms of the unknown, of reincarnation and of a strange poignant love story.

A book for those with inquiring minds who are uncommitted to orthodox concepts, and who are willing to be deeply involved and disturbed by this great and startling work.

Demy 8vo. Hardback, nearly 400 pages. 42 s. (by post 45 s. or U.S.A \$6.75)

\section{FIVE BOOKS OF WISDOM by KUTHUMI}

Material received during ten years of private seances, consisting of lectures, meditations, explanations on evolution. Karma, dogmas and reincarnation. These are the highest spiritual teachings ever given to mankind and written in a fluent simple style for easy understanding.

Demy 8 vo. Cloth. 45 s. 486 pages (by post $48 s$, or USA $\$ 8.00$ )

\section{TAROT OF THE MAGI \\ by CARLYLE A. PUSHONG}

Without any doubt the very best book about Tarot cards and their readings. Written in clear, concise style this book thoroughly paves the way for the layman to understanding mnemonic value of the Tarot.

Demy 8 vo. Cloth 18 s. (by post 20 s. or USA \$3.50)

\section{TOWARDS GOD}

\section{by REGINALD BROWNE}

This book acts as a signpost pointing the way to a clearer concept and understanding of this fast-moving world. It examines in new light aspects of life such as mental health, sex and the role of the churches. Crown 8vo. Cloth 10 s $6 d$ (by post 11 s $6 d$, or USA $\$ 2.00$ )

\section{A SEARCH FOR TRUTH by ALBERT GEISSLER}

What is now illogical and repugnant to common sense we are now asked to accept in faith. This book is the result of a thorough and progressive study of the relatively new science called Extra Sensory Perception (E.S.P.), or a study of the para-normal.

Cloth Demy 8vo. 21 s Net (by post $22 \mathrm{~s} 6 \mathrm{~d}$ or USA, Canada, etc, \$3.75)

\section{REGENCY PRESS}

(London and New York) Ltd. 43 NEW OXFORD STREET, LONDON, W.C.1. ENGLAND MANUSCRIPTS INVITED 